DOI: https://dx.doi.org/10.33289/IJRPC.10.1.2020.10(14)

\title{
SYNTHESIS AND ANTIOXIDANT ACTIVITY OF 3-[4-(2,5- \\ DIMETHYL AMINO-1H PYRROL-1-YL-PHENYL) $[1,3,4]-$ OXADIAZINO [6,5-B] SUBSTITUTED INDOLE
}

\author{
Bairy Padma* and Sammaiah Gadea \\ University College of Pharmaceutical Sciences, Kakatiya University, \\ Warangal-506 002, Telangana, India.
}

\section{ABSTRACT}

Fifteen new 3-[4-(2,5-dimethyl amino-1H pyrrol-1-yl-phenyl) [1,3,4]-oxadiazino [6,5-b] substituted indole have been synthesized. The chemical structures of the products were confirmed by ${ }^{1}$ HNMR, IR and mass spectral data. The compounds were screened for antioxidant activity by standard DPPH assay method. $\mathrm{IC}_{50}$ values of these compounds were determined. Compounds XIIf, XIIm and XIIn potent antioxidant and remaining compounds showed significant antioxidant activity. Ascorbic acid was taken as standard drug.

Keywords: Isatin, Antioxidant activity and oxadiazene.

\section{INTRODUCTION}

Isatin has been known for about 150 years and exhibit biological activity in mammals ${ }^{1}$. It is evident from literature, that isatin derivatives are known to be associated with broad spectrum of biological activity like antibacterial $^{2}$, analgesic and antiinflammatory ${ }^{3}$, anti-viral $^{4}$, antianxiety ${ }^{5}$, antihistaminic ${ }^{6}$ and antidepressant $^{7}$. In view of these properties it has been considered worthwhile to synthesize some new biologically potent isatins with an aim to screen for antioxidant activity. The synthesized compounds has been purified and characterized with the help of their analytical and spectral (IR, ${ }^{1}$ HNMR \& Mass) data.

\section{Chemistry}

The new 3-[4-(2,5-dimethyl amino-1H pyrrol-1yl-phenyl) [1,3,4]-oxadiazino [6,5-b] substituted indole have been synthesized by following Scheme-I and Characterized by IR, NMR and Mass data. Physical data of new compounds are presented in Table-1. 
<smiles>[R]c1ccc(N)cc1</smiles>

Aniline

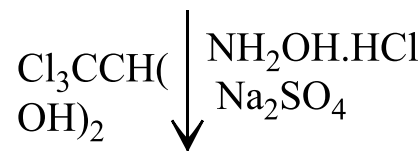<smiles>[R]c1cccc(NC(=O)/C=N/O)c1</smiles>

Isonitrosoacetanilide<smiles>[R]c1ccc2c(c1)C(=O)C(=O)N2</smiles>

III<smiles>CCOC(=O)c1ccc(N)cc1</smiles>

Ethyl-4-amino benzoăte

VIII
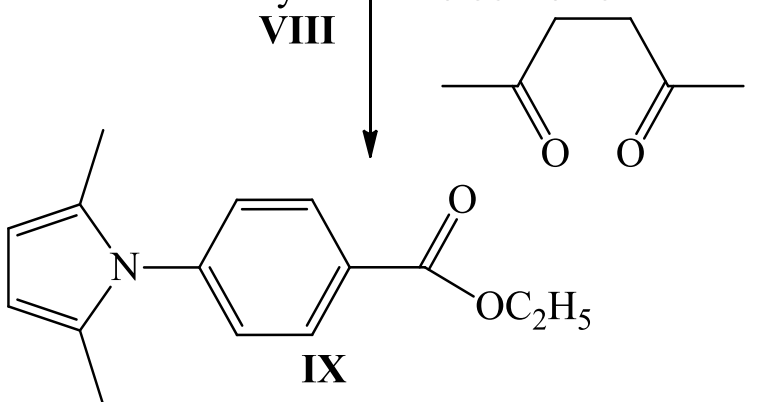

Ethyl 4-(2,5-dimethyl-1H-pyrrol-1-yl) benzoate

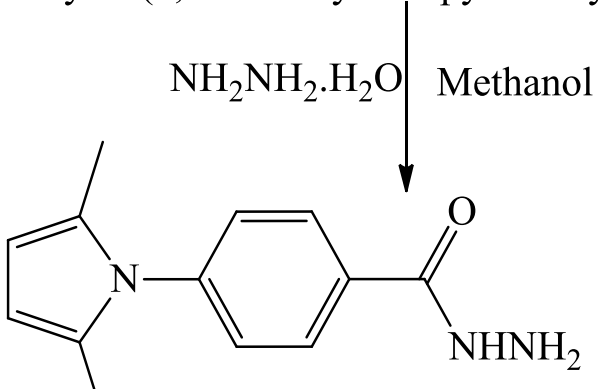

4-(2,5-dimethyl-1H-pyrrol-1-yl) benzo hydrazide $\mathbf{X}$

\section{$\mathrm{CH}_{3} \mathrm{OH} /$ glacial}

aceticacid

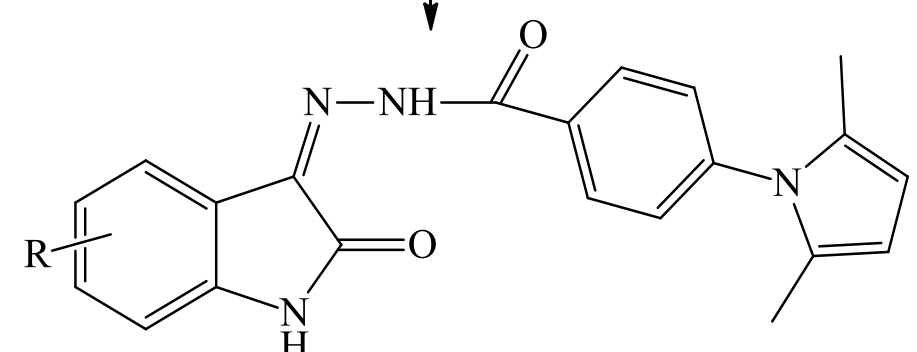

4-(2,5-dimethyl-1H-pyrrol-1-yl)-N-(2-oxoindolin-3-ylidene) benzo hydrazides<smiles>[R]c1cccc2c3nnc(-c4ccc(-n5c(C)ccc5C)cc4)oc-3nc12</smiles>

4-(2,5-dimethyl-1H-pyrrol-1-yl-phenyl)-[1,3,4-Oxadiazino [6,5-b] substituted indole

Scheme-I 
General Procedure for the synthesis of 3[4-(2,5-dimethyl amino-1H pyrrol-1-ylphenyl) [1,3,4]-oxadiazino [6,5-b] substituted indole

A. Synthesis of ethyl 4-(2,5-dimethyl-1Hpyrrol-1-yl) benzoate (IX)

A mixture of ethyl-4-aminobenzoate (VIII, 0.01 mol) and hexane-2,5-dione (II, 0.01 mol) were taken into a RB flask and dissolved in minimum amount of ethyl acetate $(10-15 \mathrm{ml})$. The reaction mixture was refluxed at $120^{\circ} \mathrm{C}$ for $5-6 \mathrm{hrs}$, progress of the reaction was monitored by TLC. The reaction mixture was cooled and extracted with ether ( 3 times with $20 \mathrm{ml}$ ) and washed with $10 \%$ citric acid $(3 \times 20 \mathrm{ml})$ and then with water $(20 \mathrm{ml})$. The organic layer was concentrated under reduced pressure to get brown liquid which solidifies at room temperature. The compound obtained was recrystallized with ethyl acetate.

B. Synthesis of 4-(2,5-dimethyl-1H-pyrrol-1yl) benzo hydrazide $(X)$

A mixture of 1:5 ratio of ethyl 4-(2,5-dimethyl$1 \mathrm{H}$-pyrrol-1-yl) benzoate (IX) and hydrazine hydrate, were transferred in to a RB flask and dissolved in minimum quantity of methanol and was refluxed for about 2 hours. The solvent was removed by distillation. The residue is triturated with crushed ice. The product, thus obtained was filtered, washed with distilled water and recrystallized from appropriate solvent.

\section{Synthesis of 4-(2,5-dimethyl-1H-pyrrol-1- yl)- $\mathrm{N}$-(2-oxoindolin-3-ylidene) benzo hydrazides (XI)}

4-(2,5-dimethyl-1H-pyrrol-1-yl) benzo hydrazide $(\mathbf{V}, 0.01 \mathrm{~mol})$ was condensed with isatin $(\mathrm{VI}, 0.01 \mathrm{~mol})$ in methanol and traces of glacial acetic acid for about 5-6 hours to get their respective 4-(2,5-dimethyl-1H-pyrrol-1-yl) -N'- (2- oxoindolin-3-ylidene) benzohydrazides. The resulting products was filtered and purified by recrystallization method.

\section{Synthesis of 4-(2,5-dimethyl-1H-pyrrol-1- yl-phenyl)-[1,3,4-Oxadiazino substituted indole (XII) \\ [6,5-b]}

A pure compound of 4-(2,5-dimethyl $-1 \mathrm{H}$ pyrrol-1-yl) -N'- (2- oxoindolin-3-ylidene) benzo hydrazides. (XI, $0.01 \mathrm{~mol}$ ) was treated with concentrated sulphuric acid and kept aside for $24 \mathrm{hrs}$. The resulting products was triturated with crushes ice and filtered and washed with distilled water. The new compound was purified by recrystallization from aqueous ethanol.
Spectral characterization data of the compound (XIla)

IR $\left(\mathrm{KBr}, \mathrm{Cm}^{-1}\right) \mathbf{v}$

$3084(\mathrm{C}-\mathrm{H}$, aromatic) 2946 (C-H of aliphatic), and $1594(\mathrm{C}=\mathrm{C}$, aromatic), 1409.80 (C-N stretch).

${ }^{1} \mathrm{H}$ NMR $\left(\mathrm{CDCl}_{3}, 300 \mathrm{MHz}, \mathrm{ppm}\right) \delta$ $2.20\left(\mathrm{~s}, 6 \mathrm{H}, \mathrm{CH}_{3}\right), 5.68$ (s, 2H, pyrrolyl), 7.18$7.40(\mathrm{~m}, 4 \mathrm{H}$, Aromatic $), 7.50-7.82(\mathrm{~m}, 4 \mathrm{H}$, Aromatic).

\section{Mass spectrum}

Recorded its heaviest ion at $\mathrm{m} / \mathrm{z} 340$, which is in agreement with the mass (mol.wt.) of its assigned structure.

Thus based on the spectral data the compound has been characterized as 3-[4(2,5-dimethyl amino-1H pyrrol-1-yl-phenyl) $[1,3,4]$-oxadiazino $[6,5-b]$ indole $(X I l a ; R=H)$.

\section{Antioxidant Activity}

\section{DPPH Radical Scavenging Method}

Blois $^{8}$ showed that $\alpha, \alpha$-diphenyl- $\beta$-picryl hydrazyl radical (DPPH) can be used for determining antioxidant activity. DPPH in ethanol shows a strong absorption band at $517 \mathrm{~nm}$ and the solution appears to be deep violet in color. As the DPPH radical is scavenged by the donated hydrogen from the antioxidant, the absorbance is diminished according to the stoichiometry. Briefly, $0.5 \mathrm{~mL}$ of DPPH solution $(0.2 \mathrm{mM})$ was mixed with $0.1 \mathrm{~mL}$ of various concentrations of test compounds and $1.5 \mathrm{~mL}$ ethanol was added. The mixture was kept at room temperature for $30 \mathrm{~min}$, and then the absorbance (OD) was read at $517 \mathrm{~nm}$ against blank. The \% reduction of free radical concentration (OD) with different concentration of test compounds was calculated and compared with standard, ascorbic acid. The results were expressed as $I_{50}$ values (the concentration of test required to scavenge $50 \%$ free radicals).

\section{RESULTS AND DISCUSSION}

The antioxidant activity of all the synthesized compounds performed using DPPH method and the results given in Table 2 . The values are expressed in $\mathrm{IC}_{50}$ that is, ability of the test compound required to decrease the concentration of test free radical by $50 \%$. Among all the test compounds, compounds XIIf, XIIm and XIlb, exhibited more potent antioxidant activity against DPPH. Remaining compounds showed mild to modetare antioxidant activity. It is proposed that DPPH may be scavenged by an antioxidant through donation of hydrogen $(\mathrm{H})$ to form a stable DPPH-H molecule which does not absorb at $517 \mathrm{~nm}$. Thus the results show 
that synthesized compounds possess antioxidant activity. It was observed that the test compounds with electron withdrawing groups (halogens) on the aromatic ring favors anti-oxidant activity.

\section{CONCLUSIONS}

A series of as 3-[4-(2,5-dimethyl amino-1H pyrrol-1-yl-phenyl) [1,3,4]-oxadiazino [6,5-b] substituted indole has been synthesized as shown in Scheme 1. The synthesized compounds were subjected to antioxidant activity, amongst the compounds tested substituent with an electron withdrawing group on the aromatic ring showing significant activity than the other substituted compounds.

Table 1: Physical data of 3-[4-(2,5-dimethyl amino-1H pyrrol-1-yl-phenyl) $[1,3,4]$-oxadiazino $[6,5-b]$ indole (Series-II)

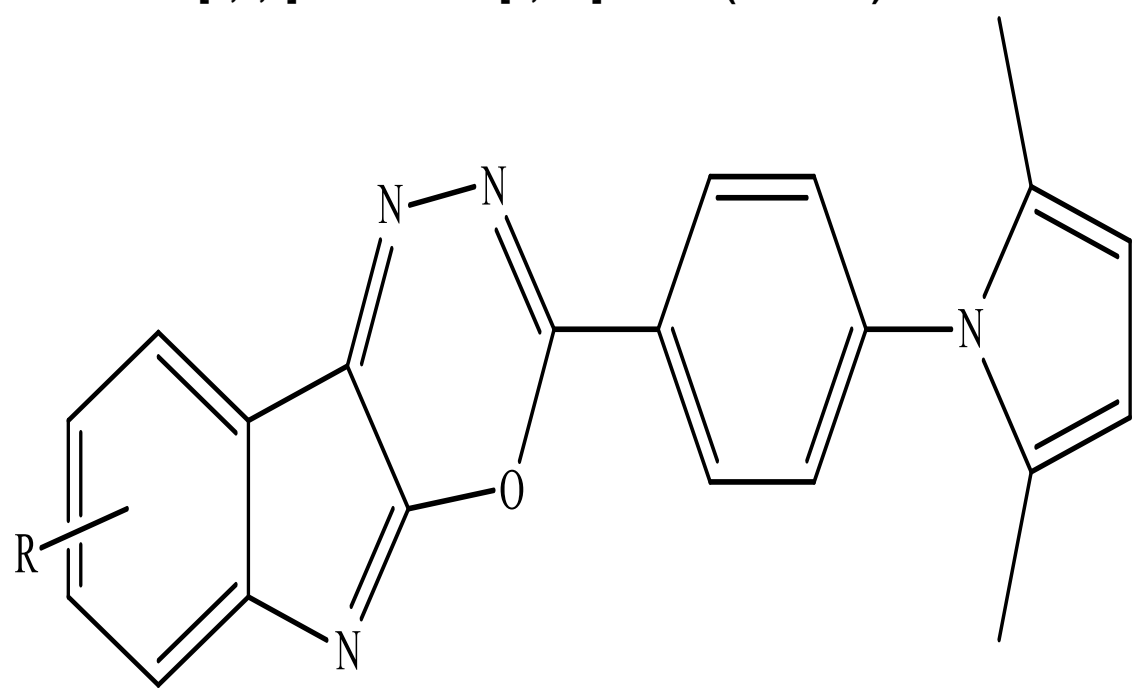

\begin{tabular}{|c|c|c|c|c|c|c|}
\hline S.No & Compound & $\begin{array}{c}\text { Substituent } \\
(\mathbf{R})\end{array}$ & Mol.Formula & Mol. Wt. & m.p ( $\left.{ }^{\circ} \mathbf{C}\right)$ & $\%$ Yield \\
\hline 1 & XIla & $\mathrm{H}$ & $\mathrm{C}_{21} \mathrm{H}_{16} \mathrm{~N}_{4} \mathrm{O}$ & 340 & $216-218$ & 45 \\
\hline 2 & XIlb & $5-\mathrm{Cl}$ & $\mathrm{C}_{21} \mathrm{H}_{15} \mathrm{~N}_{4} \mathrm{OCl}$ & 374 & $244-246$ & 86 \\
\hline 3 & XIlc & $7-\mathrm{Cl}$ & $\mathrm{C}_{21} \mathrm{H}_{15} \mathrm{~N}_{4} \mathrm{OCl}$ & 374 & $244-246$ & 84 \\
\hline 4 & XIId & $5-\mathrm{CH}_{3}$ & $\mathrm{C}_{22} \mathrm{H}_{18} \mathrm{~N}_{4} \mathrm{O}$ & 354 & $232-234$ & 81 \\
\hline 5 & XIle & $7-\mathrm{CH}_{3}$ & $\mathrm{C}_{22} \mathrm{H}_{18} \mathrm{~N}_{4} \mathrm{O}$ & 354 & $232-234$ & 79 \\
\hline 6 & XIIf & $5-\mathrm{F}$ & $\mathrm{C}_{21} \mathrm{H}_{15} \mathrm{~N}_{4} \mathrm{OF}$ & 358 & $248-250$ & 78 \\
\hline 7 & XIIg & $7-\mathrm{F}$ & $\mathrm{C}_{21} \mathrm{H}_{15} \mathrm{~N}_{4} \mathrm{OF}$ & 358 & $248-250$ & 75 \\
\hline 8 & XIlh & $5-\mathrm{Br}$ & $\mathrm{C}_{21} \mathrm{H}_{15} \mathrm{~N}_{4} \mathrm{OBr}$ & 418 & $284-286$ & 92 \\
\hline 9 & XIli & $5-\mathrm{NO}_{2}$ & $\mathrm{C}_{21} \mathrm{H}_{15} \mathrm{~N}_{5} \mathrm{O}_{3}$ & 385 & $265-267$ & 68 \\
\hline 10 & XIlj & $7-\mathrm{NO}_{2}$ & $\mathrm{C}_{21} \mathrm{H}_{15} \mathrm{~N}_{5} \mathrm{O}_{3}$ & 385 & $265-267$ & 72 \\
\hline 11 & XIlk & $5-\mathrm{OH}$ & $\mathrm{C}_{21} \mathrm{H}_{16} \mathrm{~N}_{4} \mathrm{O}_{2}$ & 356 & $221-223$ & 74 \\
\hline 12 & XIII & $7-\mathrm{OH}$ & $\mathrm{C}_{21} \mathrm{H}_{16} \mathrm{~N}_{4} \mathrm{O}_{2}$ & 356 & $221-233$ & 74 \\
\hline 13 & XIIm & $5-\mathrm{COOH}$ & $\mathrm{C}_{22} \mathrm{H}_{16} \mathrm{~N}_{4} \mathrm{O}_{3}$ & 384 & $248-250$ & 69 \\
\hline 14 & XIIn & $5-\mathrm{COOC} \mathrm{H}_{5}$ & $\mathrm{C}_{22} \mathrm{H}_{20} \mathrm{~N}_{4} \mathrm{O}_{3}$ & 412 & $243-245$ & 58 \\
\hline
\end{tabular}


Table 2: Antioxidant activity of 3-[4-(2,5-dimethyl amino-1H pyrrol-1-yl-phenyl) [1,3,4]oxadiazino $[6,5-b]$ indole (Series-II)

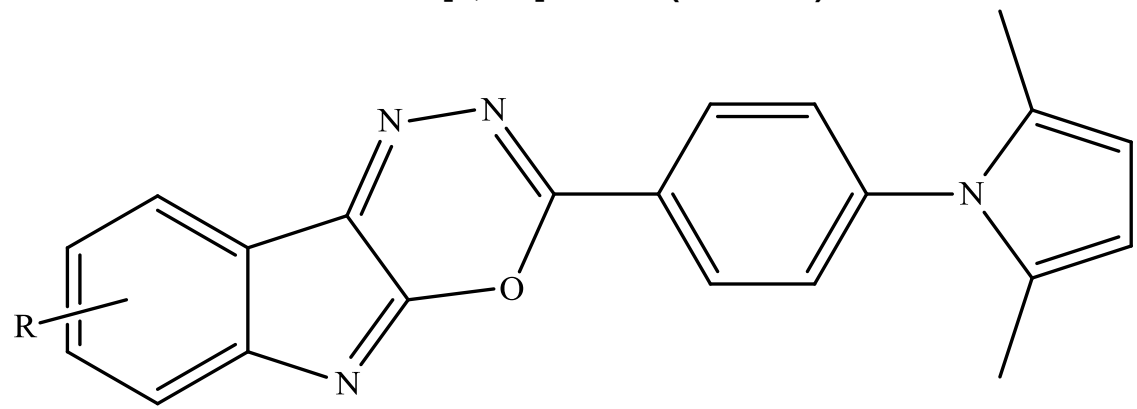

\begin{tabular}{|c|c|c|c|}
\hline S.No & Compound & $\mathbf{R}$ & $\mathrm{IC}_{50}(\mu \mathrm{g} / \mathrm{ml})$ \\
\hline 1 & XIIa & $\mathrm{H}$ & 88 \\
\hline 2 & XIIb & $5-\mathrm{Cl}$ & 42 \\
\hline 3 & XIIc & $7-\mathrm{Cl}$ & 48 \\
\hline 4 & XIId & $5-\mathrm{CH}_{3}$ & 72 \\
\hline 5 & XIle & $7-\mathrm{CH}_{3}$ & 79 \\
\hline 6 & XIIf & $5-\mathrm{F}$ & 36 \\
\hline 7 & XIIg & $7-\mathrm{F}$ & 48 \\
\hline 8 & XIIh & $5-\mathrm{Br}$ & 53 \\
\hline 9 & XIIi & $5-\mathrm{NO}_{2}$ & 62 \\
\hline 10 & XIIj & $7-\mathrm{NO}_{2}$ & 68 \\
\hline 11 & XIlk & $5-\mathrm{OH}$ & 61 \\
\hline 12 & XIII & $7-\mathrm{OH}$ & 64 \\
\hline 13 & $\mathrm{XIIm}$ & $5-\mathrm{COOH}$ & 46 \\
\hline 14 & XIIn & $5-\mathrm{COOC}_{2} \mathrm{H}_{5}$ & 59 \\
\hline 15 & Standard & Ascorbic Acid & 6.52 \\
\hline
\end{tabular}

\section{REFERENCES}

1. Somogyi L. Bull Chem Soc Jpn. 2001;74:873-881.

2. Talesara GL,Thadhaney B, Sain D and Pemawat G. Indian Journal of Chemistry. 2010;43B: 368-373.

3. Panneerselvam $P$, Kumar NR and Murali K. Der Pharma Chemica. 2010;2(1):28-37.

4. Pandeya S N, Sriram D, Nath G and DeClercq E. Eur J Pharm Sci.1999;9:25-31
5. Medvedev AE, Goodwin A, Clow A, Halket J, Glover V and Sandler M. Biochem Pharmacol. 1992;44:590592.

6. Sarangapani $M$, Swathi $K$ and Srinivas A. J Chem Pharm Res. 2010;2(2):220-225.

7. Popp FD, Parson R and Donigan BE. J Pharm Sci. 1980;69:1235-1237.

8. Blois MS. Nature. 1958;181(4617): 1199-120. 